\title{
Gene expression patterns of insulin-like growth factor 1, insulin-like growth factor 2 and insulin-like growth factor binding protein 3 in human placenta from pregnancies with intrauterine growth restriction
}

\author{
Balázs Börzsönyi ${ }^{1}$, Csaba Demendi ${ }^{1}$, Zsolt Nagy ${ }^{2}$, \\ Katalin Tóth², Mónika Csanád ${ }^{2}$, Attila Pajor ${ }^{1}$, János \\ Rigó $\mathbf{J r}^{3}$ and József Gábor Joó ${ }^{3 * *}$ \\ ${ }^{1}$ Semmelweis University, $2^{\text {nd }}$ Department of Gynecology \\ and Obstetrics, Budapest, Hungary \\ ${ }^{2}$ NAGY GÉN Diagnostics and Research Ltd., Budapest, \\ Hungary \\ ${ }^{3}$ Semmelweis University, $1^{\text {st }}$ Department of Gynecology \\ and Obstetrics, Budapest, Hungary
}

\begin{abstract}
Introduction: In this study, we compared insulin-like growth factor (IGF)-gene expression patterns and characteristics of glucose and insulin metabolism in human placenta from pregnancies with or without intrauterine growth restriction (IUGR).

Materials and methods: We compared 101 human placentas from intrauterine growth restriction pregnancies to those of 140 normal pregnancies treated at our department in a oneyear period. We have also assessed the serum glucose and insulin levels of the IUGR and control groups. Several possible predicting factors of IUGR were also investigated.

Results: Risk for IUGR was suggested by gestational weight gain and gestational increase in maternal body mass index (BMI) as well as maternal birthweight. In pregnancies without IUGR, umbilical cord glucose and insulin levels were significantly higher than in pregnancies with IUGR. In placentas from pregnancies with IUGR an overexpression of the IGF-2 and the insulin-like growth factor binding protein (IGFBP)-3 genes was found. In placentas from pregnancies with male fetal gender we found a significant overexpression of the IGF-2 gene.
\end{abstract}

Discussion: Gestational weight gain and BMI increase seem to predict the development of IUGR. Insulin and carbohydrate metabolism are also impaired in IUGR fetuses. In the placentas from pregnancies with IUGR, IGF-2 is overexpressed reflecting its physiological role in optimizing energy distribution in a low-energy environment.

\footnotetext{
*Corresponding author:

Dr. József Gábor Joó

Semmelweis Egyetem, ÁOK

I.Sz. Szülészeti és Nõgyógyászati Klinika

Baross utca 27

1088 Budapest

Hungary

E-mail: joogabor@hotmail.com
}

Keywords: Gene expression; glucose; insulin; insulin-like growth factor; intrauterine growth restriction; placenta.

\section{Introduction}

The blood flow through the uterine arteries increases significantly during a physiological pregnancy. In the first trimester it is at $50-90 \mathrm{~mL} / \mathrm{min}$, while at the end of the gestation reaches $600-700 \mathrm{~mL} / \mathrm{min}$. This increase is due to the decrease of the vascular resistance of both uterine arteries, which is the consequence of the trophoblast invasion in the spiral arteries. With normal placentation, placental circulation will be physiological and the blood supply will be suitable for a normal intrauterine development. If the placentation is pathological, the circulation of the placenta will be pathological too, and a restricted fetal growth will occur. Due to the persistent pathological circulation of the placenta, the compensatory mechanisms of the fetus run out, and hypoglycemia, acidosis and oliguria develop $[8,12]$.

Intrauterine growth restriction (IUGR) is defined as fetal birthweight at or below the $10^{\text {th }}$ percentile for sex and gestational age [40]. IUGR may result from placental dysfunction, fetal malformation, intrauterine infection or maternal factors. The most common etiology for IUGR is thought to be placental dysfunction, though its molecular level pathology remains largely unknown $[12,33]$. At the same time it has to be noted, that abnormal changes in the placental bed may occur also without IUGR, for example, in case of preeclampsia.

Glucose is the single most important energy source for intrauterine fetal growth. As fetal gluconeogenesis is minimal, the bulk of glucose is provided through transplacental glucose transport [22, 23]. Fetal hypoglycemia is very common in IUGR. The main etiology of fetal hypoglycemia is impaired transplacental glucose transport [6]. Magnusson and coworkers showed in 2004 that the principal mechanism of impaired carbohydrate metabolism in IUGR is abnormal glycolysis rather than an increased glucose demand in the placenta [22].

Intrauterine growth retardation is also associated with low insulin secretion during the pregnancy, and probably a reduced development of insuline receptors. In fetal hypoinsulinism there is a B cell hypotrophy, with consequences regarding developmental programming, such as insulin resistance [36].

It has been previously hypothesized that fetal malnutrition and the changes in the IGF axis may strongly influence and 
"program" the fetus for future pathology [29]. Both insulin and the growth factors IGF-1 and IGF-2 seem to be important in the pathogenesis of IUGR. Several studies tested umbilical cord blood levels of insulin and IGF in intrauterine growth restriction. The majority of these studies found a decreased level for both insulin and IGF [7, 11, 32], while others showed opposite results [38].

B lymphocytes are increased in women with IUGR in comparison with normal pregnancies and there is a significant negative correlation between maternal B-lymphocytes and birthweight [2].

IGF-1 is a protein with a rather complex function. The IGF-1 gene is located in chromosome 12 (12q22-24.1) It can be detected in fetal tissues from the $9^{\text {th }}$ gestational week and it appears in the fetal circulation six weeks later [1, 39]. IGF1 receptors can be identified in the early phases of pregnancy. During early fetal development, IGF-1 receptors show an enhanced sensitivity to IGF-1 compared to postnatal life [13]. Availability of IGF-1 for the fetus is regulated by six different insulin-like growth factor binding proteins (IGFBP 1-6). In the last trimester, just as during childhood and later life IGFBP-3 appears to be the main IGF-1 binding protein. Together with growth hormone (GH) IGF-1 also regulates childhood and adolescent growth.

IGF-2 is also involved in the regulation of intrauterine growth. Its gene is located in chromosome 11 (11p15.5) in close proximity to the insulin (INS) and thysorine-hydroxilase (TH) genes. The main action of IGF-2 is mediated through endocrine and autocrine stimulation of cellular differentiation [16, 30]. In the first trimester, IGF-2 is mainly produced by the fetal lungs. In the second trimester, its concentration in the amniotic fluid is about 3.2 times higher than that of IGF-1 [18].

In this study, we assessed IGF-gene expression patterns and characteristics of insulin and carbohydrate metabolism in placentas from IUGR pregnancies. We tried to find connection between the occurrence of IUGR and the maternal age, as well as to clear the eventual possibilities of predicting IUGR based on clinical information. We attempted to examine the association between the serum glucose and insulin levels, and the development of IUGR. Lastly our main aim was to compare the placental gene expression profiles of the IGFs and IGFBP-3 in normal and IUGR pregnancies, as well as in male and female fetuses. We also investigated the eventual connection between the patterns of gene expression of the IGF system and the severity of IUGR.

\section{Material and methods}

\section{Patient population}

We examined placentas from 101 pregnancies with intrauterine growth restriction treated at the Semmelweis University, Second Department of Gynecology and Obstetrics between 1 January, 2010 and 1 January, 2011 (The selection for IUGR was based on birthweight data in our department.). We compared placental gene expression patterns of IGF-1, IGF-2 and IGFBP-3 as well as the clinical characteristics (fetal gender; maternal median age; gesta- tional weight gain of the pregnant woman; gestational body mass index (BMI) increase of the pregnant woman; maternal birthweight) in the IUGR group to controls gained from 140 pregnancies without IUGR treated at our clinic in the same time period. (In certain cases the maternal birthweight was known by verbal informations.) Where no diagnosis of IUGR was made on the basis of standard definition, i.e., birthweight at or below the $10^{\text {th }}$ percentile for sex and gestational age. (However, in diagnosing IUGR fetal abdominal circumference (AC) was also strongly considered as previously described [20].) In the control group the selection criteria was the birthweight above the $10^{\text {th }}$ percentile for sex and gestational age, as well as the absence of any obstetric and genetic pathologies. Only those placentas were included in the study where IUGR was likely to be due to placental dysfunction after the exclusion of intrauterine infections, chromosomal abnormalities, developmental disorders, maternal malnutrition, multiple pregnancy and structural abnormalities in the placenta [25]. Placental dysfunction sometimes reflects abnormal placental anatomy (e.g., battledore placenta, velamentous insertion of the cord, single umbilical artery), it more frequently reflects abnormal function of a normal placenta (e.g., due to smoking, diminished perfusion, infection, infarction, chronic idiopathic villitis, etc.). In some cases abnormal placental function may be due to abnormal platelet-vessel or platelet-platelet interactions caused by insufficient production of prostacyclin, resulting in a strong vasoconstriction [37].

Delivery was either vaginal or by cesarean section based on the clinical situation. In the final analysis, no distinction was made with respect to the type of delivery.

Placental tissue samples were taken in a uniform manner (immediately after the detachment of the placenta with a sterile scalpel, always close to the origin of the umbilical cord) with approximate dimensions of $2 \mathrm{~cm} \times 2 \mathrm{~cm} \times 2 \mathrm{~cm}\left(8 \mathrm{~cm}^{3}\right)$, which were then kept at $-70^{\circ} \mathrm{C}$ for genetic expression testing. Maternal demographics and relevant clinical data during pregnancy or the perinatal period were collected including maternal and paternal age, obstetric history, genetic history, general medical history, maternal birthweight, gestational age, fetal gender, weight gain and BMI increase during pregnancy, pregnancy-related pathology including disorders of carbohydrate metabolism, neonatal weight and Apgar score. Consent was obtained in each case from the mother (signatures on file).

\section{Umbilical cord blood sampling}

In 27 pregnancies with IUGR and 32 pregnancies without, $10 \mathrm{~mL}$ blood samples were obtained from the umbilical cord to test glucose and insulin levels. Blood sampling was performed right after the delivery, before the detachment of the placenta with sterile equipment. Though the needle punction have not made the accurate localization of the sampling (artery or vein) possible, we have definitely endeavored to avoid contamination by maternal blood. Shortly after sampling, blood samples were spun at $1800 \mathrm{rpm}$ at the location of subsequent genetic testing. Samples were kept at $-70^{\circ} \mathrm{C}$ for subsequent analysis. Glucose concentration was determined by Pureauto S GLU reagent with Hitachi 7600 glucose analyzer. Insulin levels were tested with Coat-A-Coat insulin kit.

\section{RNA isolation and cDNA synthesis}

Whole placental RNA content was isolated with Quick RNA microprep kit (Zymo Research, Irvine, CA, USA). RNA concentration was determined using NanoDrop spectophotometer (NanoDrop, Wilmington, DE, USA). Reverse transcription was performed in $20 \mu \mathrm{L}$ target volume using $5 \mu \mathrm{g}$ whole RNS, 75 pmol random hexamer primer, $10 \mathrm{~mm}$ dNTP (Invitrogen, Carlsbad, CA, USA), 20 
Um-MuLV Reverse Transciptase enzyme (MBI Fermentas, Glen Burnie, MD, USA) and 1x-es buffer (MBI Fermentas). The reaction mix was incubated for $2 \mathrm{~h}$ at $42^{\circ} \mathrm{C}$. Subsequently, the enzyme was inactivated at $70^{\circ} \mathrm{C}$ for $15 \mathrm{~min}$.

\section{Real-time PCR assay}

The reverse transcriptase reaction solution was diluted 3-fold with nuclease-free water. For the real-time PCR assay, $1 \mu \mathrm{L}$ diluted cDNS (approximately $15 \mathrm{ng}$ RNA-equivalent) and 1 x SYBR Green Master Mixet (Applied Biosystems, Carlsbad, CA, USA) were used. Primers were designed using Primer Express Software (Applied Biosystems). Primer sequences are detailed in Table 1. Real-time PCR was performed in $20 \mu \mathrm{L}$ target volume using $1 \mu \mathrm{L}$ cDNA, 1 pmol, gene-specific Forward and Reverse primer and $1 \times$ SYBR Green PCR Master mix. All real-time PCR were performed using the MX3000 Real-time PCR (Stratagen, Santa Clara, CA, USA) system with the following settings: 40 cycles at $95^{\circ} \mathrm{C}$, denaturing process for $15 \mathrm{~s}$, annealing at $60^{\circ} \mathrm{C}$, chain elongation and detection for $60 \mathrm{~s}$. The sequence of genes and primers used in the real time PCR is summarized in Table 1. For each gene, relative expression was normalized using the human $\beta$-actin gene as standard.

\section{Statistical analysis}

For gene expression studies two-sample $t$-test was used with 95\% confidence interval. Determination of degree of freedom was performed using the Welch-Satterthwaite correction. Values of gene expression testing were interpreted in the following manner: (1) overexpression $=\mathrm{Ln}$ value $>1, \mathrm{P}<0.05$; (2) underexpression $=\mathrm{Ln}$ value $<-1, \mathrm{P}<0.05$; (3) normal expression $=\mathrm{Ln}$ value $<1,>-1$, $\mathrm{P}<0.05$. GraphPad Prism 3.0 (GraphPad Software Inc., La Jolla, CA, USA) software was used in all statistical analytic procedures.

Demographics and clinical data were analyzed with SPSS software. Logistic regression was used for dichotomous outcomes with multiple independent variables. For continuous outcomes, analysis of variance (ANOVA) and linear regression were used as appropriate. P-value of $<0.05$ was accepted for statistical significance.

\section{Results}

\section{Clinical data}

In the IUGR group $(\mathrm{n}=101)$, fetal gender distribution was 37 male and 64 female (male to female ratio 0.58). In the normal pregnancy group, male to female ratio was 1.09 (73 males, and 67 females).

The median birthweight of newborns from IUGR pregnancies was $2315 \pm 320 \mathrm{~g}$, while $2930 \pm 280 \mathrm{~g}$ in the control group.

The median value of the gestational age at delivery was $36.1 \pm 2.39$ weeks in the IUGR cases and $38.3 \pm 1.79$ weeks in the control group.
In the IUGR group, median maternal age was $30.82 \pm 4.34$, not statistically different from the normal pregnancy group $(31.45 \pm 3.12, \mathrm{P}>0.05)$. Analyzing IUGR outcomes by maternal age groups, we found a statistically significant difference (Cramer V: 0.23) with IUGR being more common in age groups 17-24 and 35-44 when compared to age groups 25-31 and 32-34 (Table 2).

Concerning the initial bodyweight of patients with IUGR pregnancy and normal pregnancy, no significant difference was confirmed (IUGR group: $65.9 \mathrm{~kg}$; control group: $62.6 \mathrm{~kg}$; $\mathrm{P}>0.05)$. When comparing the initial BMI values no significant differences were found (IUGR group: 24.8; control group: $23.8 ; \mathrm{P}>0.05$ ).

As it can be seen in Tables 3 and 4, there was a significant difference between the groups of normal and IUGR pregnancies, concerning the gestational weight gain and the gestational increase of BMI. In the IUGR group, mean gestational weight gain was $10.9 \mathrm{~kg}$, while in the control group it was $14.8 \mathrm{~kg}$. Similarly, in the IUGR group BMI increased by 4.1 compared to an increase of 5.3 in the control group. When gestational weight gain was either lower (3-9 kg) or higher $(14-17 \mathrm{~kg}$ ) than average, a more severe form of IUGR (birthweight $0-5$ percentile) was more likely than the "mild form", (birthweight 5-10 percentile), compared to subjects with average gestational weight gain $(10-13 \mathrm{~kg})$, associated typically with a less severe IUGR (Cramer V: 0.35) (Table 5).

As far as maternal birthweight, those mothers who delivered babies with birthweight between 0 and 5 percentile themselves had been born with a median birthweight of $2830 \mathrm{~g}$, a birthweight significantly lower than that of mothers who delivered babies with birthweight between 5 and 10 percentile. Median maternal birthweight in the latter group of mothers was $3120 \mathrm{~g}$.

\section{Umbilical cord blood tests}

In the IUGR group, both glucose and insulin levels were significantly lower than in the control group (Table 6).

\section{Gene expression studies}

We had a total of 241 placenta samples available for genetic studies; of these 101 were from pregnancies with IUGR and 140 from normal pregnancies. Gene expressions of IGF-1, IGF-2 and IGFBP-3 were then compared between the groups (Table 7). In the IUGR group, both IGF-2 and IGFBB-3 were overexpressed compared to the normal pregnancy group (IGF-2: 1.67-fold expression, $\mathrm{P}=0.04$, IGFBP-3: 1.55-fold expression, $\mathrm{P}=0.03$ ).

Table 1 Sequence of genes and primers used in the real-time PCR assay.

\begin{tabular}{|c|c|c|}
\hline Gene and accession number & Forward primer & Reverse primer \\
\hline IGF-1 (NC_000012) & 5'-AATAGAGACGGGTTTTACC-3' & 5'-TGAGGAGAATGATCATGT-3' \\
\hline IGF-2 (NC_000011) & 5'-AGCAGGTGTGTAAACAGAGG-3' & 5'-AGAGGTCCCACAGAGCTT-3' \\
\hline IGFBP3 (NC_000007) & 5'-TTCTGTTTGTGGTGAACTGA-3' & 5'-GATAGGAAGCGACAAGAAAA-3' \\
\hline$\beta$-Actin (M10277) & 5'-GGCACCCAGCACAATGAAG-3' & 5'-GCCGATCCACACGGAGTACT-3' \\
\hline
\end{tabular}


Table 2 Distribution of maternal age in the IUGR and normal pregnancy groups.

\begin{tabular}{|c|c|c|c|c|c|c|}
\hline & & \multicolumn{5}{|c|}{ Maternal age (years) } \\
\hline & & $17-24$ & $25-31$ & $32-34$ & $35-44$ & Total \\
\hline \multirow[t]{2}{*}{ Normal pregnancy } & $\mathrm{n}$ & 24 & 50 & 42 & 24 & 140 \\
\hline & $\%$ & $48.0 \%$ & $66.6 \%$ & $68.9 \%$ & $43.6 \%$ & $58.1 \%$ \\
\hline \multirow[t]{2}{*}{ IUGR pregnancy } & $\mathrm{n}$ & 26 & 25 & 19 & 31 & 101 \\
\hline & $\%$ & $52.0 \%$ & $33.3 \%$ & $31.1 \%$ & $56.4 \%$ & $41.9 \%$ \\
\hline Total & $\mathrm{n}$ & 50 & 75 & 61 & 55 & 241 \\
\hline
\end{tabular}

There was no evidence for gender difference in either IGF1 or IGFBP-3 gene expression as opposed to the IGF-2 gene, where an 1.02 -fold $(\mathrm{P}=0.03)$ overexpression was found (Table 8).

Within the IUGR group, there was no difference in IGF1, IGF-2 or IGFBP-3 gene function between those with a more severe degree of IUGR (birthweight $0-5$ percentile) vs. those with the less severe form (birthweight 5-10 percentile) (Table 9).

\section{Discussion}

In this study we found that in pregnancies with IUGR, male to female ratio was significantly lower than in the control group, which appeared to conform to the general population.

Overall, there was no difference between the groups in terms of maternal median age. However, when maternal age groups were considered it became evident that in the age groups 17-24 and 35-44 IUGR was more common than in the other groups (age groups 25-31 and 32-34; Cramer V: 0.23 ). It appears that in younger mothers and in those who are somewhat older from the obstetric-genetic viewpoint physiological growth during pregnancy may not be optimal. This phenomenon parallels the well-known fact that in younger and older mothers (over age 35) several obstetric disorders are more common including premature birth, fetal chromosomal abnormalities and IUGR itself [4, 10]. However, it must be concluded that maternal age has no significant role in the gene expression patterns of IGF-1, IGF-2 and IGFBP-3.

Table 3 Logistic regression with gestational weight gain and gestational BMI change as independent variables and IUGR or normal pregnancy as possible outcomes. This table shows, that there was a significant difference between the groups of normal and IUGR pregnancies concerning the gestational weight gain and gestational increase of body mass index (BMI). In the IUGR group, mean gestational weight gain was $10.9 \mathrm{~kg}$, while in the control group it was $14.8 \mathrm{~kg}$ (see Table 4).

\begin{tabular}{lrll}
\hline Logistic regression & \multicolumn{1}{l}{ B } & Exp(B) & P-value \\
\hline Gestational weight gain & -0.783 & 0.457 & 0.001 \\
Gestational change in BMI & 0.017 & 1.017 & 0.008 \\
Constant & 1.333 & 3.794 & 0.027 \\
\hline
\end{tabular}

In regards to the initial body weight and BMI, no significant difference was verified, though patients with IUGR pregnancy were a bit heavier, with slightly higher initial BMI values.

There was a significant difference between the groups both in gestational weight gain and gestational increase of BMI. Lower than average gestational weight gain $(12.5-13 \mathrm{~kg}$ ) [15] appeared to predict a higher risk for IUGR.

When we stratified pregnancies by gestational weight gain we found that in the groups where gestational weight gain was either low (3-9 kg) or higher than average (14-17 kg) a more severe degree of IUGR with birthweights between 0 and 5 percentile was more common than in the $10-13 \mathrm{~kg}$ group. This points to the possibility that disorders that commonly lead to increased gestational weight gain, such as impaired carbohydrate metabolism may have a role in the pathogenesis of IUGR.

Mothers that gave birth to babies with birthweight between 0 and 5 percentile had had a significantly lower birthweight themselves raising the possibility that genetic factors as well as developmental programming may influence the risk for IUGR.

Postnatal umbilical cord blood studies revealed that in the IUGR group both glucose and insulin levels were lower than in the control group. This supports similar results of prior studies [7, 19, 21].

Several nutritional, hormonal and placental factors may influence intrauterine growth. Glucose being the chief energy source for physiological fetal growth, hypoglycemia and hyperinsulinemia can lead to IUGR both in humans and in several other mammalian species [28]. Fetal hypoinsulinemia is especially important in the development of impaired bone and soft tissue growth and leads to the proportional form of IUGR [6-8, 20].

Table 4 Gestational weight gain and gestational BMI change in the IUGR and normal pregnancy groups (gestational weight gain and BMI change was not known in all cases).

\begin{tabular}{llrlrr}
\hline & \multicolumn{2}{l}{$\begin{array}{l}\text { Gestational weight } \\
\text { gain }(\mathrm{kg})\end{array}$} & & \multicolumn{2}{l}{ BMI change } \\
\cline { 2 - 3 } \cline { 5 - 6 } \cline { 5 - 6 } & Median & $\mathrm{n}$ & & Median & $\mathrm{n}$ \\
\hline Normal pregnancy & 14.7900 & 135 & & 5.3100 & 133 \\
IUGR pregnancy & 10.9000 & 95 & & 4.1100 & 74 \\
Total & 13.2000 & 230 & & 4.8900 & 207 \\
\hline
\end{tabular}


Table 5 Distribution of gestational weight gain in the group of pregnancies with more severe (neonatal birthweight 0-5 percentile) and less severe (neonatal birthweight 5-10 percentile) form of IUGR.

\begin{tabular}{|c|c|c|c|c|c|c|c|}
\hline \multirow{2}{*}{\multicolumn{2}{|c|}{$\begin{array}{l}\text { Degree of IUGR by } \\
\text { gestational weight gain }\end{array}$}} & & \multicolumn{4}{|c|}{ Gestational weight gain (kg) } & \multirow[t]{2}{*}{ Total } \\
\hline & & & $3-9$ & $10-13$ & $14-17$ & $>18$ & \\
\hline \multirow{4}{*}{$\begin{array}{l}\text { Neonatal weight } \\
\text { percentile }\end{array}$} & $0-5$ & $\mathrm{n}$ & 13 & 8 & 12 & 1 & \multirow[t]{2}{*}{34} \\
\hline & & $\%$ & $46.4 \%$ & $28.6 \%$ & $63.2 \%$ & $9.1 \%$ & \\
\hline & $5-10$ & $\mathrm{n}$ & 15 & 20 & 7 & 10 & \multirow[t]{2}{*}{52} \\
\hline & & $\%$ & $53.6 \%$ & $71.4 \%$ & $36.8 \%$ & $90.9 \%$ & \\
\hline
\end{tabular}

Table 6 Glucose and insulin levels in umbilical chord blood in neonates with IUGR or normal pregnancy.

\begin{tabular}{lccc}
\hline & Newborns with IUGR $(\mathrm{n}=27)$ & Normal newborns $(\mathrm{n}=32)$ & P-value \\
\hline Glucose concentration $(\mathrm{mg} / \mathrm{dL})$ & $24.2 \pm 12.6$ & $41.3 \pm 10.6$ & 0.01 \\
Insulin-concentration $(\mathrm{ng} / \mathrm{mL})$ & $2.4 \pm 0.8$ & $4.9 \pm 3.0$ & 0.01 \\
\hline
\end{tabular}

Table 7 Placental gene expression patterns of IGF-1, IGF-2 and IGFBP-3 in the IUGR group vs. normal pregnancy group as control.

\begin{tabular}{lllllrlll}
\hline Name of gene & $\Delta \mathrm{Ct}_{\text {normal }} \pm \mathrm{SE}^{\mathrm{a}}$ & $\Delta \mathrm{Ct}_{\mathrm{IUGR}} \pm \mathrm{SE}^{\mathrm{b}}$ & $\alpha$ value $\pm \mathrm{SE}(\alpha)^{\mathrm{c}}$ & $\mathrm{Ln} 2^{\alpha}$ & $\mathrm{LCL}$ & $\mathrm{UCL}$ & P-value & Gene expression \\
\hline IGF-1 & $3.18 \pm 0.82$ & $3.10 \pm 0.7$ & $0.08 \pm 0.5$ & 0.05 & -1.36 & 3.95 & 0.16 & No change \\
IGF-2 & $4.56 \pm 0.93$ & $2.14 \pm 0.48$ & $2.42 \pm 0.57$ & 1.67 & 0.64 & 3.77 & 0.04 & Up-regulated \\
IGFBP-3 & $4.82 \pm 0.76$ & $2.57 \pm 0.64$ & $2.25 \pm 0.43$ & 1.55 & 0.21 & 4.02 & 0.03 & Up-regulated \\
\hline
\end{tabular}

${ }^{\mathrm{a}} \Delta \mathrm{Ct}_{\text {normal }}=\mathrm{Ct}_{\text {tested gene }}-\mathrm{Ct}_{\beta \text {-actin }},{ }^{\mathrm{b}} \Delta \mathrm{Ct}_{\mathrm{IUGR}}=\mathrm{Ct}_{\text {tested gene }}-\mathrm{Ct}_{\beta \text {-actin }},{ }^{\mathrm{c}} \alpha=\Delta \mathrm{Ct}_{\text {normal }}-\Delta \mathrm{Ct}_{\mathrm{IUGR}} ; \mathrm{UCL}=$ upper confidence limit; LCL $=$ lower confidence limit; $\mathrm{n}_{\text {normal }}=140 ; \mathrm{n}_{\text {IUGR }}=101(\mathrm{P}<0.05$; significant $)$.

In our genetic expression assays, we found a significant difference between the groups in the expression patterns of IGF-2 and IGFBP-3 though not in IGF-1. In the former two, significant overexpression was found. The overexpression of the placental IGF-2 gene was previously shown in some studies [20,33], though not confirmed in others [34]. One of the most significant papers, discussing the role of IGF-2 in the placental and fetal growth, suggests that the gene of IGF-2 control both the placental supply and the genetic demand for maternal nutrients [3]. These data confirm our results that IGF-2 gene overexpression may play a role in the pathophysiology of IUGR.

Insulin-like growth factors influence both metabolic and non-metabolic components of intrauterine growth. While IGF-1 primarily affects nutritional intake, the main role of IGF-2 appears to be mediated through its general regulating effects on cellular growth and tissue-specific cell proliferation [9]. It is possible that the overexpression of the IGF-2 gene may have the function to ascertain optimal, prioritized distribution of energy to the tissues in a low-energy environ-

Table 8 Placental gene expression patterns of IGF-1, IGF-2 and IGFBP-3 in the male IUGR fetus vs. female IUGR fetus as control.

\begin{tabular}{lllllrlll}
\hline Name of gene & $\Delta \mathrm{Ct}_{\text {female }} \pm \mathrm{SE}^{\mathrm{a}}$ & $\Delta \mathrm{Ct}_{\text {male }} \pm \mathrm{SE}^{\mathrm{b}}$ & $\alpha$ value $\pm \mathrm{SE}(\alpha)^{\mathrm{c}}$ & $\mathrm{Ln} 2^{\alpha}$ & $\mathrm{LCL}$ & $\mathrm{UCL}$ & $\mathrm{P}$-value & Gene expression \\
\hline IGF-1 & $3.36 \pm 0.33$ & $2.84 \pm 0.50$ & $0.52 \pm 0.41$ & 0.36 & -0.74 & 0.82 & 0.06 & No change \\
IGF-2 & $2.88 \pm 0.60$ & $1.40 \pm 0.35$ & $1.48 \pm 0.70$ & 1.02 & 0.85 & 1.45 & 0.03 & Up-regulated \\
IGFBP-3 & $3.12 \pm 0.93$ & $2.02 \pm 0.68$ & $1.10 \pm 0.71$ & 0.76 & -0.17 & 1.27 & 0.05 & No change \\
\hline
\end{tabular}

${ }^{\mathrm{a}} \Delta \mathrm{Ct}_{\text {female }}=\mathrm{Ct}_{\text {tested gene }}-\mathrm{Ct}_{\beta \text {-actin }},{ }^{\mathrm{b}} \Delta \mathrm{Ct}_{\text {male }}=\mathrm{Ct}_{\text {tested gene }}-\mathrm{Ct}_{\beta \text {-actin }},{ }^{\mathrm{c}} \alpha=\Delta \mathrm{Ct}_{\text {female }}-\Delta \mathrm{Ct}_{\text {male }} ; \mathrm{UCL}=$ upper confidence limit; $\mathrm{LCL}=$ lower confidence limit; $\mathrm{n}_{\text {female }}=64 ; \mathrm{n}_{\text {male }}=37$ ( $\mathrm{P}<0.05$; significant).

Table 9 Placental gene expression patterns of IGF-1, IGF-2 and IGFBP-3 in the more severe form of IUGR (neonatal birthweight 0-5 percentile) vs. less severe form (neonatal birthweight 5-10 percentile) as control.

\begin{tabular}{lcccrcc}
\hline Name of gene & $\Delta \mathrm{Ct}_{\mathrm{A}} \pm \mathrm{SE}^{\mathrm{a}}$ & $\Delta \mathrm{Ct}_{\mathrm{B}} \pm \mathrm{SE}^{\mathrm{b}}$ & $\alpha$ value $\pm \mathrm{SE}(\alpha)^{\mathrm{c}}$ & $\mathrm{Ln} 2^{\alpha}$ & $\mathrm{P}_{\text {-value }}$ & Gene expression \\
\hline IGF-1 & $3.2 \pm 0.72$ & $2.98 \pm 0.5$ & $0.22 \pm 0.39$ & 0.15 & 0.08 & No change \\
IGF-2 & $1.95 \pm 0.4$ & $2.35 \pm 0.6$ & $-0.4 \pm 0.42$ & -0.27 & 0.05 & No change \\
IGFBP-3 & $2.8 \pm 0.81$ & $2.3 \pm 0.47$ & $0.5 \pm 0.6$ & 0.34 & 0.04 & No change \\
\hline
\end{tabular}

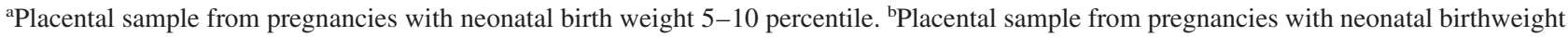
0-5 percentile; $\Delta \mathrm{Ct}_{\mathrm{A}}=\mathrm{Ct}_{\text {tested gene }}-\mathrm{Ct}_{\beta \text {-actin }}, \Delta \mathrm{Ct}_{\mathrm{B}}=\mathrm{Ct}_{\text {tested gene }}-\mathrm{Ct}_{\beta \text {-actin }},{ }^{\mathrm{c}} \alpha=\Delta \mathrm{Ct}_{\mathrm{A}}-\Delta \mathrm{Ct}_{\mathrm{B}} ; \mathrm{n}_{\mathrm{A}}=54 ; \mathrm{n}_{\mathrm{B}}=38(\mathrm{P}<0.05 ;$ significant $)$. 
ment. This effect appears analogous to the redistribution mechanism observed in intrauterine asphyxia [14]. The thrifty phenotype hypothesis states that this energy redistribution in IUGR comes at a price: it predicts an increased risk for diabetes and cardiovascular problems in later postnatal life $[14,31]$.

Availability of IGF-1 and IGF-2 is regulated by six different binding proteins. Among these, the role of IGFBP-1 is known and discussed in the literature [17], while that of IGFBP-3 is less significantly expressed in papers dealing with the connection of IGF system and IUGR, and the results are quite inconsistent. In contrast to our findings, prior studies showed overexpression of the IGFBP-1 rather than the IGFBP-3 gene in the IUGR placenta. Meio et al. and other papers concluded from their examinations that newborns with IUGR have significantly reduced IGFBP-3 levels at birth, which suggests, that its gene is underexpressed $[5,11$, 24]. At the same time Murisier-Petetin et al. and Tisi et al. verified a high amniotic fluid concentration of IGFBP-3 in the second trimester from pregnancies with IUGR $[26,35]$. Anyway our results based on a numerous sample confirms, that IGFBP-3 gene overexpression plays an important role in the pathophysiology of IUGR. It was previously supposed, that IGFBP-3 may potentiate IGF action, and is associated to the changes in the insulin and carbohydrate metabolism. IGFBP-3 has both inhibitory and stimulatory effects in cell systems, and modulates growth. IGFBP-3 also works as reservoir of IGF-1, carrying it to target cells [24]. It has been verified that IGFBP-3 increases the bioeffectiveness of IGF1 by 2 - to 4 -fold. As IGF-1 primarily affects nutritional intake, its effectivity in the function can be positively influenced by IGFBP-3, which may explain the placental overexpression of the IGFBP-3 gene.

In the IUGR group, the IGF-2 gene was overexpressed in the placenta from pregnancies with male fetal gender. There was no such gender difference in the function of either the IGF-1 or the IGFBP-3 genes. This fetal gender-specific overexpression of the IGF-2 gene was previously observed in the amniotic fluid of normal pregnancies [27]. This may reflect a possible physiological role of IGF-2 in the development of gender-specific phenotype.

There seemed to be no relationship between the severity of IUGR and expression patterns of the tested genes. It appears that the severity of IUGR is therefore not primarily linked to the IGF system. Other genetic and constitutional factors may play a more predominant role in this regard.

In summary, we found that intrauterine growth restriction is more common with maternal age around 20 or above 35 . Risk for IUGR is predicted by gestational weight gain and gestational increase in maternal BMI as well as maternal birthweight. In intrauterine growth restriction, glucose and insulin levels are significantly lower in the umbilical cord blood than in normal pregnancy. In human placenta from pregnancies with IUGR the placental IGF-2 and IGFBP-3 genes are significantly overexpressed compared to placental IGF-2 and IGFBP-3 from normal pregnancies. Based on these an eventual connection may be supposed between the development of chronic diseases in the adulthood and the risk of developing IUGR. In intrauterine growth restriction, the placental IGF-2 gene is overexpressed in the male fetus reflecting the role of IGF-2 in the development of genderspecific phenotype. In our study, we could not detect a relationship between the severity of IUGR and patterns of gene expression of the IGF system.

\section{Acknowledgements}

I would like to acknowledge the significant contribution of my colleagues at the $1^{\text {st }}$ and $2^{\text {nd }}$ Department of Obstetrics and Gynecology Semmelweis University in making the study. I would also like to thank the participation of my colleagues at the Nagy Gén Diagnostics and Research Ltd.

\section{References}

[1] Ashton IK, Zapf J, Einschenk I, MacKenzie IZ. Insulin-like growth factors (IGF) I and II in human fetal plasma and relationship to gestational age and fetal size during midpregnancy. Acta Endocrinol (Copenh). 1985;110:558-63.

[2] Bartha JL, Comino-Delgado R. Lymphocyte subpopulations in intrauterine growth retardation in women with or without previous pregnancies. Eur J Obstet Gynecol Reprod Biol. 1999;82:23-7.

[3] Constancia M, Hemberger M, Hughes J, Dean W, FergusonSmith A, Fundele R, et al. Placental-specific IGF-2 is a major modulator of placental and fetal growth. Nature. 2002;417: 945-8.

[4] Cunningham FG, Leveno KJ. Childbearing among older women - the message is cautiously optimistic. N Engl J Med. 1995;333:1002-4.

[5] De Zegher F, Francois I, van Helvoirt M, van den Berghe G. Clinical review 89: small as fetus and short as child: from endogenous to exogenous growth hormone. J Clin Endocrinol Metabol. 1997;82:2021-6.

[6] Economides DL, Nicolaides KH. Blood glucose and oxygen tension levels in small-for-gestational-age fetuses. Am J Obstet Gynecol. 1989;160:385-9.

[7] Economides DL, Proudler A, Nicolaides KH. Plasma insulin in appropriate- and small-for-gestational-age fetuses. Am J Obstet Gynecol. 1989;160:1091-4.

[8] Fowden AL. Endocrine regulation of fetal growth. Reprod Fertil Develop. 1995;7:351-63.

[9] Fowden AL. The insulin-like growth factors and feto-placental growth. Placenta. 2003;24:803-12.

[10] Fraser AM, Brockert JE, Ward RH. Association of young maternal age with adverse reproductive outcomes. N Engl J Med. 1995;332:1113-7.

[11] Giudice LC, de Zegher F, Gargosky SE, Dsupin BA, de las Fuentes L, Crystal RA, et al. Insulin-like growth factors and their binding proteins in the term and preterm human fetus and neonate with normal and extremes of intrauterine growth. J Clin Endocrinol Metabol. 1995;80:1548-55.

[12] Gluckman PD, Harding JE. The physiology and pathophysiology of intrauterine growth retardation. Horm Res. 1997;48 (Suppl 1):11-6.

[13] Gluckman PD, Grumbach MM, Kaplan SL. The neuroendocrine regulation and function of growth hormone and prolactin in mammalian fetus. Endo Rev. 1981;2:363-95. 
[14] Hales CN, Barker DJ. The thrifty phenotype hypothesis. Br Med Bull. 2001;60:5-20.

[15] Hytten FE, Thomson AM. Maternal physiological adjustments. In: Assali NS, editors. Biology of gestation, Vol. I. The maternal organism. New York: Academic Press; 1968.

[16] Jones JI, Clemmons DR. Insulin-like growth factors and their binding proteins: biological actions. Endo Rev. 1995;16:3-34.

[17] Kajimura S, Aida K, Duan C. Insulin-like growth factorbinding protein-1 (IGFBP-1) mediates hypoxia-induced embryonic growth and developmental retardation. Proc Natl Acad Sci USA. 2005;102:1240-5.

[18] Kubota T, Kamada S, Taguchi M, Aso T. Determination of insulin-like growth factor-2 in feto-maternal circulation during human pregnancy. Acta Endocrinol. 1992;127:359-65.

[19] Kuo PL. Glucose gradients of maternal vein-umbilical artery in normally grown and growth-retarded fetuses. J Perinat Med. 1991;19:421-5.

[20] Lee JJ. Birth weight for gestational age patterns by sex, plurality and parity in Korean populations. Korean J Perinatol. $2007 ; 18: 1-11$.

[21] Lee MH, Jeon YJ, Lee MS, Park MH, Jung SC, Kim YJ. Placental gene expression is related to glucose metabolism and fetal cord blood levels of insulin and insulin-like growth factors in intrauterine growth restriction. Early Hum Dev. 2010;86:45-50.

[22] Magnusson AL, Powell T, Wennergren M, Jansson T. Glucose metabolism in the human preterm and term placenta of IUGR fetuses. Placenta. 2004;25:337-46.

[23] Marconi AM, Cetin I, Davoli E, Baggiani AM, Fanelli R, Fennessey PV, et al. An evaluation of fetal glucogenesis in intrauterine growth-retarded pregnancies. Metabolism. 1993;42:860-4.

[24] Meio MDB, Moreira MEL, Sichieri R, Moura AS. Reduction of IGF-binding protein-3 as a potential marker of intrauterine growth restriction. J Perinat Med. 2009;37:689-93.

[25] Lee MH, Jeon YJ, Lee SM, Park MH, Jung SC, Kim YJ. Placental gene expression is related to glucose metabolism and fetal cord blood levels of insulin and insulin-like growth factors in intrauterine growth restriction. Early Hum Develop. 2010;86:45-50.

[26] Murisier-Petetin G, Gremlich S, Damnon F, Reymondin D, Hohlfeld P, Gerber S. Amniotic fluid insulin-like growth factor binding protein 3 concentration as early indicator of fetal growth restriction. Eur J Obstet Gynecol Reprod Biol. 2009; 144:15-20.

[27] Nagy Zs, Börzsöniy B, Demendi CS, et al. Gender specific gene expression of IGF-1 and IGF-2 in second trimester amniotic fluid cells. Obstet Gynecol. 2011 (under review).

[28] Neitzke U, Harder T, Plagemann A. Intrauterine growth restriction and developmental programming of the metabolic syndrome: a critical appraisal. Microcirculation. 2011;18: 304-11.

[29] Ozanne SE, Hales N. Early programming of glucose-insulin metabolism. Trends Endocrin Metabol. 2002;13:368-73.

[30] Pahlman S, Meyerson G, Lindgren E, Schalling M, Johansson I. Insulin-like growth factor I shifts from promoting cell division to potentiating maturation during neuronal differentiation. Proc Natl Acad Sci USA. 1991;88:9994-8.

[31] Plagemann A. A matter of insulin: developmental programming of body weight regulation. J Maternal Fetal Neonatal Med. 2008;21:143-8.

[32] Samaan NA, Schultz PN, Johnston DA, Creasy RW, Gonik B. Growth hormone, somatomedin $\mathrm{C}$, and non-suppressible insulin-like activity levels compared in premature, small, average birth weight, and large infants. Am J Obstet Gynecol. 1987; 157:1524-8.

[33] Sheikh S, Satoskar P, Bhartiya D. Expression of insulin-like growth factor-I and placental growth hormone mRNA in placentae: a comparison between normal and intrauterine growth retardation pregnancies. Mol Hum Reprod. 2001;7:287-92.

[34] Street ME, Seghini P, Fieni S, Ziveri MA, Volta C, Martorana $D$, et al. Changes in interleukin-6 and IGF system and their relationships in placenta and cord blood in newborns with fetal growth restriction compared with controls. Eur J Endocrinol. 2006;155:567-74.

[35] Tisi DK, Liu XJ, Wykes LJ, Skinner CD, Koski KG, et al. Insulin-like growth factor II and binding proteins 1 and 3 from second trimester human amniotic fluid are associated with infant birth weight. J Nutr. 2005;135:1667-72.

[36] Van Assche FA, Holemans K, Aerts L. Fetal growth and consequences for later life. J Perinat Med. 1998;26:337-46.

[37] Varner MW. Disproportionate fetal growth. In: DeCherney AH, Pernoll ML, editors. Current obstetric \& gynecologic diagnosis \& treatment. East Norwalk: Appleton \& Lange; 1994. pp. 344-56.

[38] Wang HS, Lim J, English J, Irvine L, Chard T. The concentration of insulin-like growth factor-I and insulin-like growth factor-binding protein-1 in human umbilical cord serum at delivery: relation to fetal weight. J Endocrinol. 1991;129: 459-64.

[39] Wang HS, Chard T. The role of insulin-like growth factor-I and insulin-like growth factor-binding protein-1 in the control of human fetal growth. J Endocrinol. 1992;132:11-9.

[40] Wollmann HA. Intrauterine growth restriction: definition and etiology. Horm Res. 1988;49(Suppl 2):1-6.

The authors stated that there are no conflicts of interest regarding the publication of this article.

Received April 7, 2011. Revised June 22, 2011. Accepted June 24, 2011. Previously published online July 30, 2011. 